Mia Peric ${ }^{1}$

ORIGINAL PAPER

Natasa Zenic ${ }^{1}$

Damir Sekulic ${ }^{1,2}$

Miran Kondric ${ }^{3}$

Petra Zaletel ${ }^{3}$

\title{
DISORDERED EATING, AMENORRHEA, AND SUBSTANCE USE AND MISUSE AMONG PROFESSIONAL BALLET DANCERS: PRELIMINARY ANALYSIS
}

\author{
ZABURZENIA ODŻYWIANIA, BRAK MIESIACCZKI ORAZ UŻYWANIE I NADUŻYWANIE SUBSTANCJI PSYCHOAKTYWNYCH \\ I PRZECIWBÓLOWYCH WŚRÓD PROFESJONALNYCH TANCEREK BALETOWYCH - ANALIZA WSTĘPNA
}

\author{
${ }^{1}$ University of Split, Split, Croatia \\ Faculty of Kinesiology \\ ${ }^{2}$ University of Split, Split, Croatia \\ Department of Health Studies \\ ${ }^{3}$ University of Ljubljana, Ljubljana, Slovenia \\ Faculty of Sport
}

\begin{abstract}
Background: Substance use and misuse (SUM), eating disorders (ED) and consequent amenorrhea (AM) occur frequently in professional ballet dancing. The objective of this study has been to explore the prevalence and association between ED, AM and SUM in ballet. Material and Methods: The sample comprised 21 ballet dancers, $23.1 \pm 4.5$ years old, members of the professional National Ballet Ensemble from Croatia. Variables were collected by questionnaires examining SUM, occurrence of amenorrhea, and corresponding ballet-specific and socio-demographic factors (Questionnaire on Substance Use - QSU) and the level of ED (Brief Eating Disorder in Athletes Questionnaire - BEDA-Q). Results: Smoking is prevalent in $40 \%$ of dancers (25\% smoke on a daily basis), 36\% often use analgesics, and $25 \%$ engage in binge drinking at least once a month. Smoking and binge drinking are less frequent in ballerinas with a higher academic level $(\mathrm{r}=0.60$ and $\mathrm{r}=0.54$ for binge drinking and smoking, respectively; $\mathrm{p}<0.05)$. Alcohol drinking is higher among dancers who consume analgesics more often and those with a higher BEDA-Q score $(\mathrm{r}=0.53$ and $\mathrm{r}=0.54$ for analgesics and BEDA-Q, respectively; $\mathrm{p}<0.05$ ). Amenorrhea is more prevalent among those dancers with a higher BEDA-Q score. Women who consume nutritional supplements are less likely to use analgesics (Mann Whitney U test $=2.11 ; \mathrm{p}<0.05$ ). Conclusions: Efforts seeking to prevent ED in ballet should target dancers who consume alcohol to a greater extent. Future studies should specifically explore the less frequent consumption of analgesics among dancers who consume nutritional supplements. Med Pr 2016;67(1):21-27
\end{abstract}

Key words: amenorrhoea, professional dancers, dietary supplements, binge drinking, tobacco smoking, eating behaviors

\section{STRESZCZENIE}

Wstep: Używanie i nadużywanie substancji psychoaktywnych i przeciwbólowych (substance use and misuse - SUM), zaburzenia odżywiania (eating disorders - ED) i w konsekwencji brak miesiączki (amenorrhea - AM) często występują u profesjonalnych tancerek baletowych. Celem badania było określenie związku między SUM, ED i AM oraz częstości ich występowania u baletnic. Materiał i metody: Zbadano 21 profesjonalnych tancerek baletowych w wieku 23,1 $\pm 4,5$ roku z chorwackiego Zespołu Baletu Narodowego. W badaniu wykorzystano Kwestionariusz Używania Substancji Psychoaktywnych (Questionnaire on Substance Use - QSU) i Skrócony Kwestionariusz Zaburzeń Odżywiania u Sportowców (Brief Eating Disorder in Athletes Questionnaire BEDA-Q). Wyniki: Badanie wykazało, że 40\% tancerek paliło papierosy (25\% codziennie), 36\% często używało środków przeciwbólowych, a 25\% upijało sie przynajmniej raz w miesiącu. Rzadziej upijały się i paliły baletnice z wyższym wykształceniem (odpowiednio: $r=0,60$ i $r=0,54$; $p<0,05)$ niż bez wyższego wykształcenia. Konsumpcja alkoholu była natomiast większa u tancerek częściej używających leków przeciwbólowych i tych, które uzyskały wyższy wynik kwestionariusza BEDA-Q (odpowiednio: $\mathrm{r}=0,53$ i $\mathrm{r}=0,54 ; \mathrm{p}<0,05$ ), niż u tych, które używały leków przeciwbólowych rzadziej, i tych z niższym wynikiem BEDA-Q. Również brak miesiączki występował częściej u tancerek z wyższym wynikiem BEDA-Q. Baletnice spożywające suplementy diety stosowały środki przeciwbólowe rzadziej (test Manna-Whitneya $=2,11 ; \mathrm{p}<0,05)$ niż tancerki niespożywające suplementów. Wnioski: Programy zapobiegania zaburzeniom odżywiania wśród tancerek baletowych należy kierować przede wszystkim do spożywających alkohol w dużych ilościach. W przyszłych badaniach szczególnie warto skupić się na zależności między rzadkim używaniem środków przeciwbólowych a stosowaniem suplementów diety. Med. Pr. 2016;67(1):21-27

Słowa kluczowe: brak miesiączki, tancerki zawodowe, suplementy diety, upijanie się, palenie papierosów, nawyki żywieniowe

Corresponding author / Autorka do korespondencji: Natasa Zenic, University of Split, Faculty of Kinesiology,

Teslina 6, 21000 Split, Croatia, e-mail: natasazenic@yahoo.com

Received: June 30, 2015, accepted: November 24, 2015 


\section{INTRODUCTION}

Ballet dancing is a highly specific occupation and professional activity that is often an exclusive source of income for the person involved. Ballet dancers practise and/or perform most days with little off-season time. They dance through pain and under high psychological stress, perform in challenging environments and constantly risk career-threatening injuries. As a result, ballet dancers have a high risk of several occupational health hazards [1-3]. More specifically, the aesthetic ideal of female ballet dancers is characterized by a low body weight, an androgynous appearance and a high degree of flexibility [1]. It is generally accepted that such a body type assures gentle and gracious movement. Consequently, ballet dancers are at a high risk of eating disorders (ED) [4]. At the same time, ballet is a physically and physiologically stressful occupation, with a high prevalence of substance use and misuse (SUM) [5].

Male ballet dancers consume alcohol to a great extent and this is explained by specific stress, similar to that known to occur in professional athletes [5]. At the same time, the prevalence of cigarette smoking among their female peers is found to be alarming, with more than $35 \%$ of daily smokers in a sample of professional ballet dancers from 2 ensembles in Croatia $[3,5,6]$. Namely, the high prevalence of smoking in females relates to the fact that ballerinas are more aware of their body weight than their male colleagues and, as a result, smoke tobacco in order to increase their basal metabolism $[5,7,8]$. Approximately $70 \%$ of female dancers consume some type of nutritional or dietary supplements as a logical consequence of the high physical demands of their profession [3,5]. Finally, more than $30 \%$ of female and about $20 \%$ of male ballet professionals report frequent/regular use of painkillers - analgesics [5].

Studies have repeatedly reported the injury occurrence and factors associated with injury occurrence as characteristic occupational risks in ballet dancers $[9,10]$. However, other health-related issues in ballet such as SUM, ED and the occurrence of amenorrhea are rarely investigated. Moreover, there is an evident lack of studies that examined the interrelationships between these factors.

Therefore, the primary objective of this study has been to examine the prevalence of the SUM and ED among female ballet professionals. In addition, we have examined associations between socio-demographic factors, the SUM, ED and the occurrence of amenor-

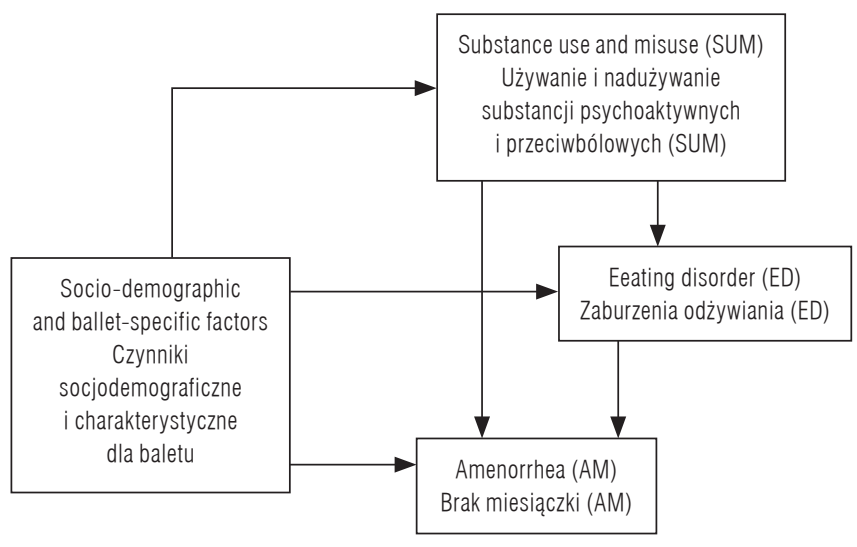

Fig. 1. Study design of SUM, ED and AM among professional ballet dancers

Ryc. 1. Projekt badania SUM, ED i AM wśród profesjonalnych tancerek baletowych

rhea in the studied sample of dancers. The study design is presented in the Figure 1.

The following hypotheses were formulated:

the SUM and socio-demographic factors will be related to the ED,

the SUM, socio-demographic factors and the ED will be related to the occurrence of amenorrhea.

\section{MATERIAL AND METHODS}

The participants in this study were 21 professional female ballet dancers who were tested in November 2014 . At the time of the investigation, the participants were aged 17-32 and had participated in ballet-related programs, such as training and performance, for 25-30 h per week. They had been involved in ballet for more than 8 years and were current members of the ballet ensemble of the Croatian National Theatre (CNT) in Split, Croatia. Prior to this study, formal permission from the CNT authorities had been obtained. The first author's Institutional Ethical Board reviewed and approved the study (No. 2181-205-02-05-14-004, 17 June 2014). The participants were informed that they could refuse participation and withdraw from the study at any time, for any reason, and their informed consent was obtained. Participation was anonymous and no personal data directly connected to an individual was included in the study.

Four sets of variables were observed:

specific ballet factors and socio-demographic factors,

SUM data,

data on the occurrence of amenorrhea,

ED data. 
Variables were collected with 2 questionnaires, the Questionnaire of Substance Use (QSU), and the Brief Eating Disorder in Athletes Questionnaire (BEDA-Q), previously used and validated for similar samples of participants $[3,5,11]$.

The QSU consists of questions asking the participants about several socio-demographic factors such as sex, age, education level, marriage and family, experience in ballet, consumption of substances (cigarettes, alcohol, and drugs), and amenorrhea.

Cigarette smoking was asked on a 6-point scale ranging from "never smoked" to "smoke more than a pack daily." The consumption of alcohol was measured by the Alcohol Use Disorders Identification Test (AUDIT) scale (the scale contains 10 items with scores 0-4 for a hypothetical minimum of 0 to a maximum of 40) [12], and binge alcohol drinking (a 5-point scale ranging from "I don't drink alcohol at all" to "binging a couple of times per week"). The consumption of drugs, cannabis, opiates, painkillers, appetite suppressants were answered on a 3-point scale with the responses "never," "occasionally" and "regularly/often"). Question on nutritional supplementation was dichotomous ("yes," "no") [5]. For the purpose of this study, the participants were asked about the occurrence of amenorrhea (responses included: "never," "rarely," "from time to time," or "often") $[3,5]$.

The BEDA-Q is a brief inventory, a tool to evaluate the level of disordered eating [13]. The version we have used here consists of the following 6 items asking participants about eating-disorder symptoms:

- "I feel extremely guilt after overeating,"

"I am preoccupied with the desire to be thinner,"

"I think that my stomach is too big,"

"I feel satisfied with the shape of my body,"

"My parents have expected excellence of me,"

"As a child, I tried very hard to avoid disappointing my parents and teachers."

The potential responses included: "always," "usually," "often," "sometimes," "rarely," or "never." The responses are scored ( $3=$ always, $2=$ usually, $1=$ often, $0=$ sometimes, $0=$ rarely, $0=$ never; reversely for the 4th item), and the theoretical final result for each participant ranged 0-18. In addition, the BEDA-Q includes 3 questions on dieting, as follows: "Are you trying to lose weight now"? ("yes," "no"); "Have you tried to lose weight during your career"? ("yes," "no"); "If yes, how many times have you tried to lose weight $(1-2,3-5$, or $>5$ times)"? [11].

Statistics included frequencies and percentages for the QSU questions, and the means (M) and standard deviations (SD) for the BEDA-Q. Whereas the majority of the QSU variables were ordinal, the associations between variables were evaluated by means of the Spearman's rank-order correlation. Furthermore, a MannWhitney $U$ test was applied to identify differences between characteristic groups of dancers (nutritional supplement users vs. non-users; involved vs. non-involved in dieting). To determine the multivariate relationships between the studied ballet-specific, socio-demographic and the SUM data (i.e., predictors), with the ED score a forward stepwise multiple regression analysis was applied. Moreover, we calculated 3 sets of forward stepwise conditional binary logistic regressions to define the relationships between the predictors and:

the occurrence of amenorrhea (observed on a binomial scale: "yes," "no"),

the binomial variable "losing weight currently" ("yes," "no"),

ever tried to lose weight ("yes," "no").

A value of $\mathrm{p}<0.05$ was considered statistically significant. The statistical analyses were performed using Statistica version 12 (prod. Statsoft, USA).

\section{RESULTS}

Binge drinking once a month was self-reported by $26 \%$ of the dancers, while $5 \%$ binge drink more than once a week. Daily cigarette smoking is prevalent in $25 \%$ of the dancers, with an additional $15 \%$ who smoke but not on a daily basis. Other drugs (including most 'party drugs', cannabis and hashish) are consumed by $35 \%$ of the dancers. Nutritional supplements are used by $58 \%$ of them. Analgesics (painkillers) are consumed by $90 \%$ of the dancers $(53 \%$ and $37 \%$ for occasional and regular/frequent usage, respectively). Furthermore, $63 \%$ of the dancers had tried to lose weight during their ballet career, $32 \%$ had tried it 3 times or more, while $10 \%$ of them had been trying to lose weight during the period of testing.

In addition to logical correlations that will not be specifically discussed here, such as the correlation between age and experience in ballet, there are several associations that deserve special attention with regard to the study aims. Cigarette smoking and binge drinking are less prevalent among ballerinas with a higher academic level $(r=-0.60$ and $r=-0.54$ for binge drinking and smoking, respectively, both at $\mathrm{p}<0.05)$. Alcohol drinking as measured by means of the AUDIT scale is higher among dancers who more often consume analgesics (painkillers) and those with higher scores 
on the BEDA-Q ( $r=0.53$ and $r=0.54$ for painkillers

scores for the BEDA-Q are related to the occurrence of and the BEDA-Q, respectively; both at $\mathrm{p}<0.05)$. High amenorrhea $(\mathrm{r}=0.51 ; \mathrm{p}<0.05)($ Table 1$)$.

Table 1. Spearman's rank order correlation between studied variables

Tabela 1. Korelacja rang Spearmana między badanymi zmiennymi

\begin{tabular}{|c|c|c|c|c|c|c|c|c|}
\hline \multirow{2}{*}{$\begin{array}{l}\text { Parameter } \\
\text { Parametr }\end{array}$} & \multicolumn{8}{|c|}{$\begin{array}{l}\text { Spearman's rank order correlation } \\
\text { Korelacja rang Spearmana }\end{array}$} \\
\hline & $\begin{array}{l}\text { age of respondents } \\
\text { wiek badanych }\end{array}$ & 1 & 2 & 3 & 4 & 5 & 6 & 7 \\
\hline 1. Experience in ballet / Doświadczenie w balecie & $0.68^{*}$ & & & & & & & \\
\hline 2. Education / Wykształcenie & 0.08 & -0.04 & & & & & & \\
\hline 3. Binge drinking / Upijanie się & 0.12 & 0.27 & $-0.60^{*}$ & & & & & \\
\hline 4. AUDIT & -0.15 & 0.21 & 0.19 & 0.28 & & & & \\
\hline 5. Cigarette smoking / Palenie papierosów & -0.11 & -0.12 & $-0.54^{*}$ & -0.16 & 0.04 & & & \\
\hline $\begin{array}{l}\text { 6. Analgesics consumption / Używanie środków } \\
\text { przeciwbólowych }\end{array}$ & 0.41 & 0.07 & 0.36 & -0.05 & $0.53^{*}$ & 0.35 & & \\
\hline 7. BEDA-Q & -0.08 & 0.19 & 0.04 & -0.01 & $0.54^{*}$ & 0.16 & -0.21 & \\
\hline 8. Amenorrhea occurrence / Brak miesiączki & $-0.46^{*}$ & -0.28 & 0.20 & -0.19 & 0.20 & 0.26 & 0.02 & $0.51^{*}$ \\
\hline
\end{tabular}

AUDIT - Alcohol Use Disorders Identification Test / Test Rozpoznawania Zaburzeń Związanych z Piciem Alkoholu [12,17], BEDA-Q - Brief Eating Disorder in Athletes Questionnaire / Skrócony Kwestionariusz Zaburzeń Odżywiania u Sportowców [11].

* Statistically significant at $\mathrm{p}<0.05 /$ Istotność statystyczna przy $\mathrm{p}<0,05$.

Table 2. Forward stepwise multiple regression between independent variables and result on BEDA-Q

Tabela 2. Wielokrotna regresja krokowa między zmiennymi niezależnymi a wynikiem BEDA-Q

\begin{tabular}{lcccc}
\hline \multicolumn{1}{c}{$\begin{array}{c}\text { Parameter } \\
\text { Parametr }\end{array}$} & $\beta$ & SE $\beta$ & B & SE B \\
\hline Interception coefficient / Współczynnik intercepcji & & & -0.67 & 0.66 \\
AUDIT & 0.31 & 0.15 & 0.28 \\
R & $0.59^{*}$ & & \\
\hline
\end{tabular}

$\beta$ - standardized coefficient / współczynnik standaryzowany, SE - standard error / błąd standardowy, B - non-standardized coefficient / współczynnik niestandaryzowany, $\mathrm{R}$ - multiple correlation / korelacja wielokrotna.

Other abbreviations as in Table $1 /$ Inne objaśnienia jak w tabeli 1.

Table 3. Forward stepwise logistic regression between independent variables and occurrence of amenorrhea in professional ballet dancers observed as binomial criterion Tabela 3. Logistyczna regresja krokowa między zmiennymi niezależnymi a brakiem miesiączki u profesjonalnych tancerek baletowych jako kryterium dwumianowe

\begin{tabular}{lcc}
\hline \multirow{2}{*}{$\begin{array}{c}\text { Parameter } \\
\text { Parametr }\end{array}$} & \multicolumn{2}{c}{$\begin{array}{c}\text { Amenorrhea } \\
\text { Brak miesiączki }\end{array}$} \\
\cline { 2 - 3 } Constant / Stała & OR & $95 \%$ CI \\
BEDA-Q & 0.26 & \\
\hline
\end{tabular}

BEDA-Q - as in Table $1 /$ jak w tabeli 1.

OR - odds ratio / iloraz szans, CI - confidence interval / przedział ufności.
Table 4. Forward stepwise logistic regression between independent variables and professional ballet dancers' attempts to lose weight observed as binomial criteria

Tabela 4. Logistyczna regresja krokowa między zmiennymi niezależnymi a odchudzaniem się profesjonalnych tancerek baletowych jako kryterium dwumianowe

\begin{tabular}{ccc}
\hline $\begin{array}{c}\text { Parameter } \\
\text { Parametr }\end{array}$ & $\begin{array}{c}\text { Losing weight } \\
\text { Odchudzanie się }\end{array}$ \\
\cline { 2 - 3 } & $\begin{array}{c}\text { at the moment } \\
\text { obecnie }\end{array}$ & $\begin{array}{c}\text { throughout the career } \\
\text { w trakcie kariery }\end{array}$ \\
\hline Constant / Stała (OR) & 0.14 & 0.16 \\
Experience in ballet / Doświadczenie \\
w balecie [OR (95\% CI)]
\end{tabular}

Abbreviations as in Table 3 / Skróty jak w tabeli 3. 
Those ballet dancers who consume nutritional supplements are less likely to use analgesics (Mann-Whitney $\mathrm{U}$ test $=2.11 ; \mathrm{p}<0.05)$.

The BEDA-Q score is found to be higher among dancers with a higher AUDIT score (Table 2).

Amenorrhea is more prevalent among those dancers with a higher BEDA-Q score (odds ratio $(\mathrm{OR})=3.13$; $95 \%$ confidence interval $(\mathrm{CI})=1.02-17.14)($ Table 3$)$. The logistic regression did not reach statistical significance for the criterion "currently losing weight." On the other hand, the greater likelihood of "losing weight throughout the career" is evidenced in more experienced dancers $(\mathrm{OR}=6.52 ; 95 \% \mathrm{CI}=1.11-22.13)$ (Table 4$)$.

\section{DISCUSSION}

The results have generally confirmed both study hypotheses. In short:

the consumption of alcohol is found to be associated with the BEDA-Q (i.e., ED), while,

BEDA-Q results are associated with occurrence of amenorrhea in professional ballet dancers.

Prior to discussing those findings, we will briefly overview descriptive data on the SUM.

Our results demonstrate that $26 \%$ of the dancers report binge drinking at least once a month, and $1 / 3$ of the dancers often use analgesics. These findings are consistent with previous reports [5]. By contrast, extensive publichealth efforts against cigarette smoking have resulted in the decreased prevalence of smoking among ballet dancers. Compared to previous studies, the smoking prevalence in this sample ( $25 \%$ of daily cigarette smokers) is significantly lower than the prevalence reported for Croatian ballet dancers 5 and 10 years ago ( $41 \%$ and $37 \%$ daily smokers for 2005 and 2010, respectively) $[5,6]$.

High alcohol consumption is a common strategy to cope with occupational stress, and the simultaneous use of analgesics and alcohol in sport and exercise is a known problem $[5,13,14]$. But, to the best of our knowledge, this is the 1st study to report this among ballet dancers. Specifically, analgesic consumption poses special risks for regular users of alcohol, including acetaminophen toxicity and gastrointestinal bleeding associated with non-steroidal anti-inflammatory drug use [15]. We suggest that ballet dancers misuse both substances for similar reasons, such as musculoskeletal pain, but they should be specifically advised of the health-related hazards of this behavior.

Alcohol has a caloric (i.e., energetic) value and alcohol consumption is therefore not expected to be preva- lent among persons who place an emphasis on a lean figure, such as dancers and athletes involved in socalled aesthetic sports [3]. Furthermore, alcohol may contribute to a positive energy balance not only via its additive effects on the total energy intake but also by stimulating appetite in the short term. Therefore, the association between alcohol consumption and a higher score on the BEDA-Q is somewhat unexpected. However, it is possible that those dancers who misuse alcohol are not aware of the final consequences of this behavior (i.e., a positive energy balance), which may result in dissatisfaction with their overall physical appearance and the consequent ED.

The female-athlete triad, which includes the ED, amenorrhea and low bone mineral density, is frequently reported in aesthetic sports and ballet dancing [16] Therefore, the established association between the BEDA-Q results and occurrence of amenorrhea is one of the most important findings of this study. Although previous studies on ballet reported amenorrhea among dancers who suffered the serious ED such as anorexia nervosa, our results show an association between relatively low levels of the ED and amenorrhea (i.e., even the maximum result for the BEDA-Q reported for our sample is not alarming and corresponds to the theoretical mean of the BEDA-Q scale) [11].

There is growing evidence of the increased prevalence of nutritional supplementation (NS) in sport, exercise and physically demanding jobs [17]. Many controversies remain about the possible efficacy and necessity of this behavior [18]. Yet it is also confirmed that the NS provide potentially important nutrients for those individuals who are involved in physically demanding activities [19]. Nutritional supplementation cannot replace a dancer's genetic potential, training regime or overall psychosocial preparation, but the most favorable NS strategies have been studied and have often proven to be beneficial.

Optimal nutrition may reduce fatigue and injuries, promote recovery from injuries, optimize the body's energy stores and consequently positively influence one's health status [18-20]. Due to the training duties and performances, dancers are frequently unable to eat adequately and therefore the relatively high prevalence of the NS in our participants (almost $2 / 3$ of the dancers consume the NS) is not surprising and is consistent with previous reports $[3,5]$. Interestingly, those dancers who consume the NS are less likely to use analgesics. While due to its cross-sectional nature this study cannot define the true cause and effect relationship between 
the variables, it is possible that the NS provide dancers with nutrients lacking in their regular diet, resulting in improved recovery after strenuous exercise and performance. Consequently, future studies should more precisely explore the background of these findings.

Although decreasing globally, cigarette smoking remains the 6th leading cause of death worldwide, and excessive alcohol consumption is related to numerous negative social consequences [12,21]. Moreover, alcohol drinking and cigarette smoking are related to injury occurrence and impaired recovery after physical exercise/work [17,22]. Therefore, although not directly related to our main study aims, the positive association between academic achievement and smoking and binge drinking calls for attention and further evaluation.

\section{Limitations and strengths of the study}

The main limitation of this study arises from its crosssectional nature and relatively small sample size. However, we tested nearly the entire professional ensemble in one National Theatre. We also did not explore the problem qualitatively, but this was intentional since such a study approach would almost certainly compromise the anonymity of the participants. The primary strength of the investigation is that this is one of the 1st investigations to explore the associations between the SUM, amenorrhea and the ED among ballet dancers. In addition, the study is a partial continuation of our previous investigations performed 5 years ago, which allows us to objectively compare the results with those obtained before on similar samples of subjects.

\section{CONCLUSIONS}

Alcohol consumption in ballet remains high. These findings are particularly important because of the established association between alcohol consumption and the consumption of analgesics. Furthermore, ballet dancers should be specifically advised of the risks of high alcohol consumption, such as impaired recovery after strenuous exercise and injury occurrence.

Although the data on the ED does not reveal an alarming prevalence of the ED, a higher level of the ED occurs among dancers who consume more alcohol. Therefore, prevention efforts against the ED in ballet should target dancers who consume larger amounts of alcohol. Also, even moderate level of the ED is found to be associated to amenorrhea among dancers.

Future studies should elucidate the reason that ballet dancers who consume more of the NS are less likely to consume analgesics. Because pain and consequent injury occurrence is one of the greatest occupational health risks of ballet dancing, the potentially positive effects of the NS on pain prevalence deserves special attention.

\section{ACKNOWLEDGMENTS}

Special thanks to all dancers who voluntarily participated in the study. The support of Mr Dinko Bogdanic, the principal of the National Ballet Ensemble is gratefully acknowledged.

\section{REFERENCES}

1. Wanke EM, Mill H, Arendt M, Wanke A, Koch F, Groneberg DA. Occupational accidents in professional dancers with regard to different professional dance styles. Work. 2014;49(4):597-606, http://dx.doi.org/10.3233/ WOR-131736.

2. Thomas JJ, Keel PK, Heatherton TF. Disordered eating and injuries among adolescent ballet dancers. Eat Weight Disord. 2011;16(3):e216-22, http://dx.doi.org/10.1007/BF 03325136.

3. Zenic N, Peric M, Zubcevic NG, Ostojic Z, Ostojic L. Comparative analysis of substance use in ballet, dance sport, and synchronized swimming: Results of a longitudinal study. Med Probl Perform Art. 2010;25(2):75-81.

4. Nascimento AL, Luna JV, Fontenelle LF. Body dysmorphic disorder and eating disorders in elite professional female ballet dancers. Ann Clin Psychiatry. 2012;24(3):191-4.

5. Sekulic D, Peric M, Rodek J. Substance use and misuse among professional ballet dancers. Subst Use Misuse. 2010;45(9):1420-30, http://dx.doi.org/10.3109/10826 081003682198 .

6. Oreb G, Ruzic L, Matkovic B, Misigoj-Durakovic M, Vlasic J, Ciliga D. Physical fitness, menstrual cycle disorders and smoking habit in Croatian National Ballet and National Folk Dance Ensembles. Coll Antropol. 2006;30(2):279-83.

7. Louis-Sylvestre J. [Tobacco and weight]. Rev Praticien. 1993;43(10):1235-7. French.

8. Perkins KA. Metabolic effects of cigarette smoking. J Appl Physiol. 1992;72(2):401-9.

9. Ekegren CL, Quested R, Brodrick A. Injuries in preprofessional ballet dancers: Incidence, characteristics and consequences. J Sci Med Sport. 2014;17(3):271-5, http://dx.doi.org/10.1016/j.jsams.2013.07.013.

10. Steinberg N, Aujla I, Zeev A, Redding E. Injuries among talented young dancers: Findings from the UK Centres for Advanced Training. Int J Sports Med. 2014;35(3): 238-44, http://dx.doi.org/10.1055/s-0033-1349843. 
11. Martinsen M, Holme I, Pensgaard AM, Torstveit MK, Sundgot-Borgen J. The development of the brief eating disorder in athletes questionnaire. Med Sci Sport Exer. 2014;46(8):1666-75, http://dx.doi.org/10.1249/ MSS.0000000000000276.

12. Zenic N, Terzic A, Rodek J, Spasic M, Sekulic D. Genderspecific analyses of the prevalence and factors associated with substance use and misuse among Bosniak adolescents. Int J Envir Res Public Health. 2015;12(6):6626-40, http://dx.doi.org/10.3390/ijerph120606626.

13. Stępka E, Basińska MA. [Chronic fatigue and strategies of coping with occupational stress in police officers]. Med Pr. 2014;65(2):229-38, http://dx.doi.org/10.13075/ mp.5893.2014.033. Polish.

14. Sekulic D, Milanovic I, Bok D, Jukic I, Matika D. Substance use and misuse in the Croatian Army Special Forces: Prevalence and influencing factors. Int J Occup Med Environ Health. 2014;27(1):123-31, http://dx.doi. org/10.2478/s13382-014-0241-4.

15. Dart RC. The use and effect of analgesics in patients who regularly drink alcohol. Am J Manag Care. 2001;7 (19 Suppl):S597-601.

16. Hincapie CA, Cassidy JD. Disordered eating, menstrual disturbances, and low bone mineral density in dancers: A systematic review. Arch Phys Med Rehabil. 2010;91(11):1777-89, http://dx.doi.org/10.1016/j.apmr. 2010.07.230.
17. Sekulic D, Bjelanovic L, Pehar M, Pelivan K, Zenic N. Substance use and misuse and potential doping behaviour in rugby union players. Res Sport Med. 2014;22(3):226-39, http://dx.doi.org/10.1080/15438627.2014.915839.

18. Kondric M, Sekulic D, Petroczi A, Ostojic L, Rodek J, Ostojic $\mathrm{Z}$. Is there a danger for myopia in anti-doping education? Comparative analysis of substance use and misuse in Olympic racket sports calls for a broader approach. Subst Abuse Treat Prev Policy. 2011;6:27, http:// dx.doi.org/10.1186/1747-597X-6-27.

19. Rodek J, Sekulic D, Kondric M. Dietary supplementation and doping-related factors in high-level sailing. J Int Soc Sports Nutr. 2012;9(1):51, http://dx.doi.org/10.1186/15502783-9-51.

20. Sajber D, Rodek J, Escalante Y, Olujic D, Sekulic D. Sport nutrition and doping factors in swimming; Parallel analysis among athletes and coaches. Coll Antropol. 2013;37(Suppl 2):179-86.

21. Sekulic D, Ostojic M, Ostojic Z, Hajdarevic B, Ostojic L. Substance abuse prevalence and its relation to scholastic achievement and sport factors: An analysis among adolescents of the Herzegovina-Neretva Canton in Bosnia and Herzegovina. BMC Public Health. 2012;12:274, http://dx.doi.org/10.1186/1471-2458-12-274.

22. Price TB, Krishnan-Sarin S, Rothman DL. Smoking impairs muscle recovery from exercise. Am J Physiol Endocrinol Metab. 2003;285(1):E116-22, http://dx.doi. org/10.1152/ajpendo.00543.2002.

This work is available in Open Access model and licensed under a Creative Commons Attribution-NonCommercial 3.0 Poland License / Ten utwór jest dostępny w modelu open access na licencji Creative Commons Uznanie autorstwa - Użycie niekomercyjne 3.0 Polska - http://creativecommons.org/ licenses/by-nc/3.0/pl/deed.en. 